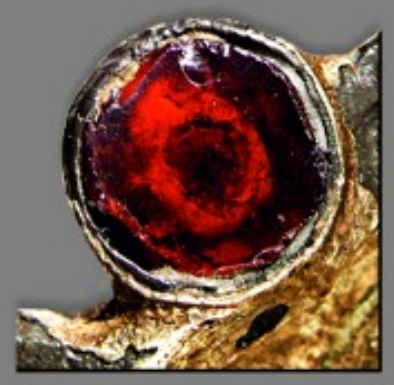

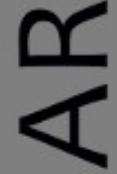

$\sim$

ш
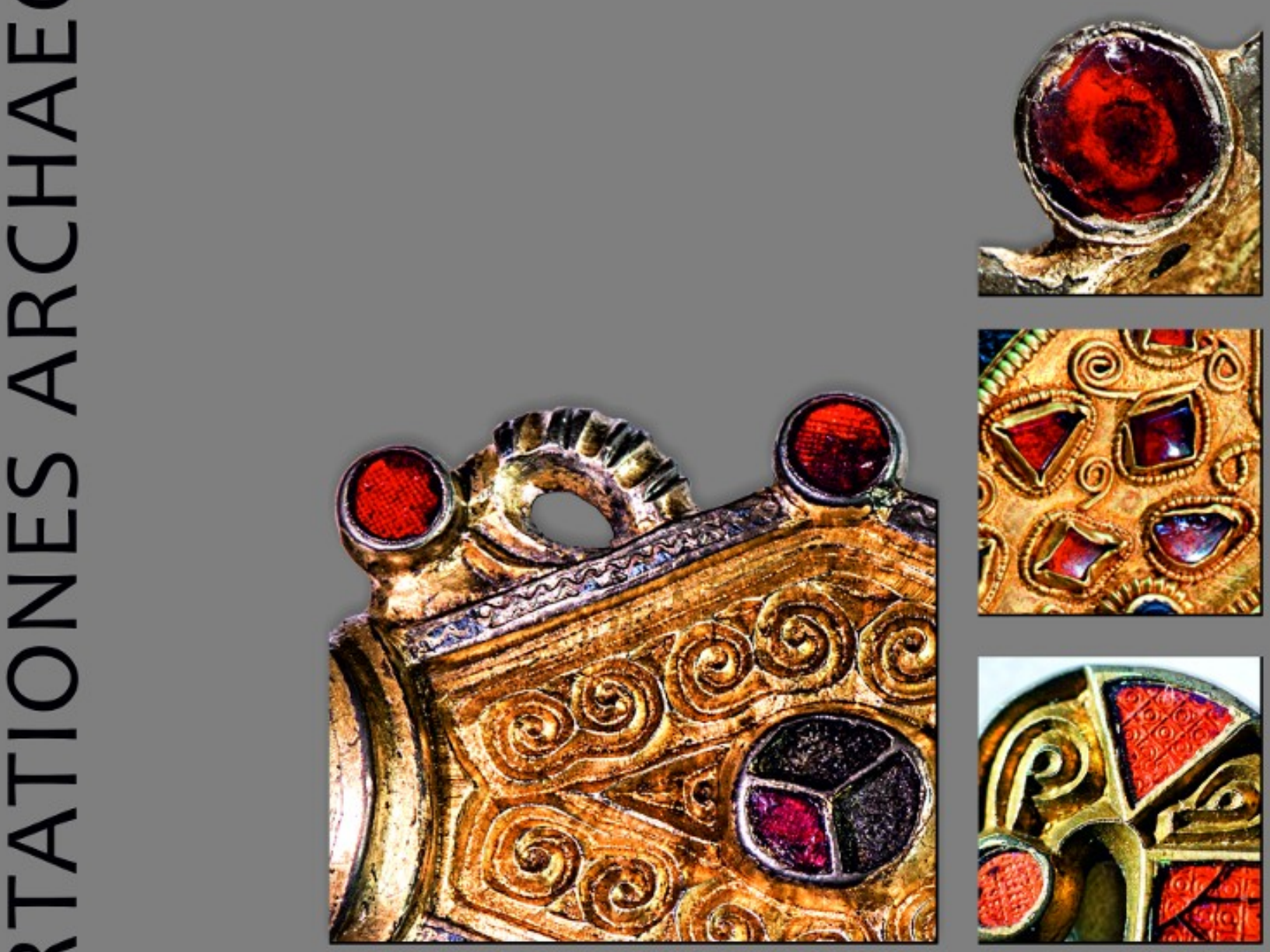

E

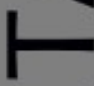

œ

山

n

ก

$\overline{0}$
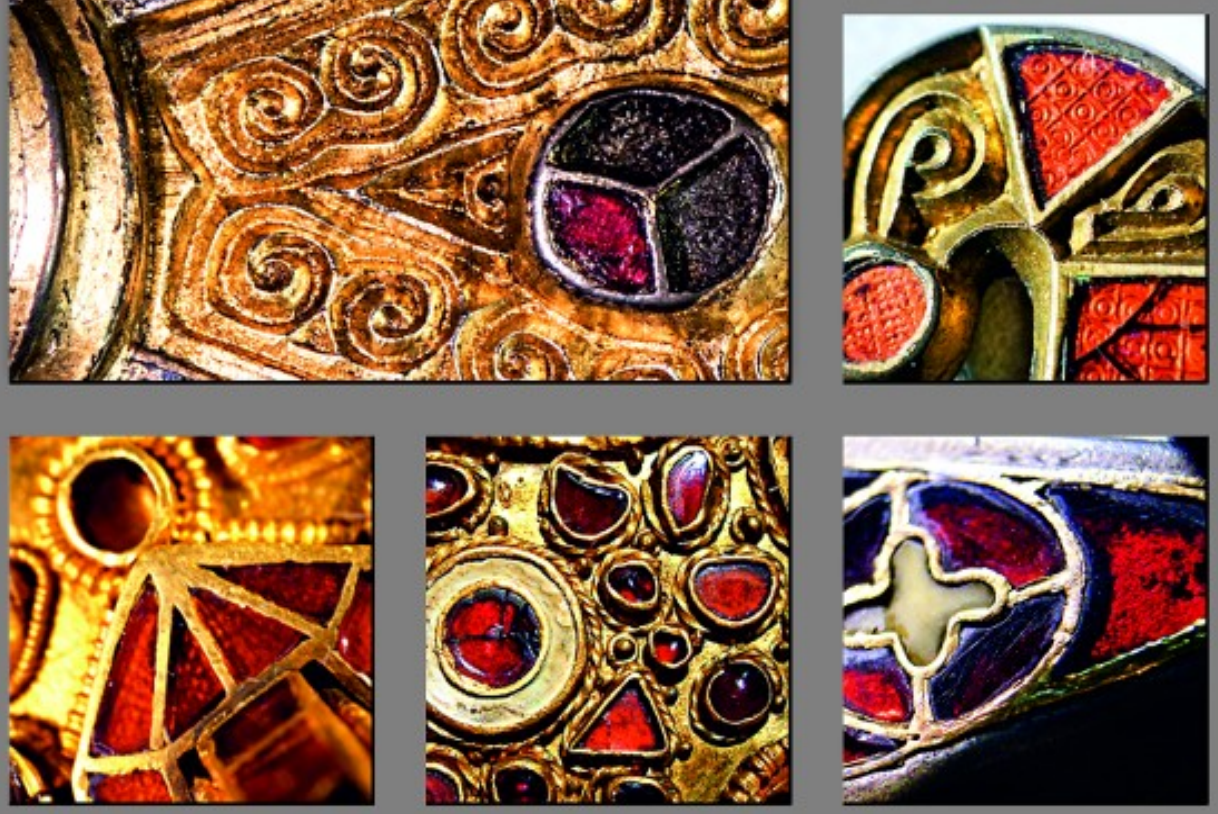

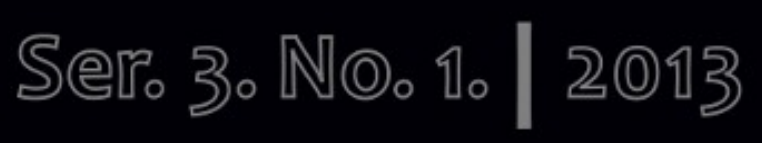




\section{Dissertationes Archaeologicae ex Instituto Archaeologico}

Universitatis de Rolando Eötvös nominatae Ser. 3. No. 1.

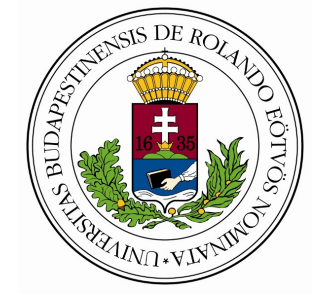

Budapest 2013 
Dissertationes Archaeologicae ex Instituto Archaeologico

Universitatis de Rolando Eötvös nominatae

Ser. 3. No. 1.

Editor-in-chief:

DÁvid BARTUS

Editorial board:

LÁSZLÓ BARTOSIEWICZ

LÁSZLÓ BORHY

ISTVÁN FELD

GÁBOR KALLA

PÁL RACZKY

Miklós SzABÓ

TIVADAR VIDA

Technical editors:

DÁvid BARTuS

GÁBOR VÁCZI

ANDRÁs BöDŐcs

Proofreading:

Zsófia KondÉ

SzILvia SzÖLlősI

Available online at http://dissarch.elte.hu

Contact: dissarch@btk.elte.hu

\section{$\underline{\text { PKP }}$ \\ PUBLIC \\ KNOWLEDGE \\ PROJECT}

(C) Eötvös Loránd University, Institute of Archaeological Sciences

Budapest 2013 


\section{Contents}

\section{Articles}

Melinda TORBÁGYI - István VIDA

The coin hoard of Abasár

Anikó BózsA

21

Roman mirrors from a private collection in the Hungarian National Museum

Lajos JuHÁsz

45

The Biesheim cameo - a reinterpretation

\section{Methods}

Péter CsIPpÁN

$A z$ állatcsont, mint információhordozó leletanyag

Kata DÉvAI

Terminológiai alapfogalmak régészeti korú üvegtárgyak elemzéséhez

Lőrinc TimáR - Zoltán Czajlik - Sándor Puszta - Balázs Holl

$3 D$ reconstructions using GPR data at the Mont Beuvray

\section{FIELD REPORTS}

Zsolt MESTER

Excavation at a new Upper Palaeolithic site of the Eger region (Northern Hungary)

László BORHY - Dávid BARTus - Emese SzÁmadó

Short report on the excavations at Brigetio (Szőny-Vásártér) in 2013

Dénes HulLÁm - Zsófia RÁcz

Report on the participation of the Eötvös Loránd University at the Wielbark Archaeological Field School in Malbork-Wielbark, Poland

Gábor VÁczi - Dávid BARTus

Short report on the excavations at the site Makó - Igási Ugar

Maxim MoRdovin

Short report on the excavations in 2013 of the Department of Hungarian Medieval and Early Modern Archaeology (Eötvös Loránd University, Budapest)

\section{THESIS ABSTRACTS}

Kitti KÖHLER

Biological reconstruction of the Late Neolithic Lengyel Culture 
Cultural connections and interactions of Eastern Transdanubia during the Urnfield period

Orsolya LÁNG

Urban problems in the civil town of Aquincum: the so-called „northern band”

Nikoletta SEY

Questions of bronze workshops in Roman Pannonia

Kata DÉvaI

Glass vessels from Late Roman times found in graves in the Hungarian part of Pannonia

Eszter HORvÁTH

Gemstone and glass inlaid fine metalwork from the Carpathian Basin:

the Hunnic and Early Merovingian Periods

Gergely SzEnTHE

Vegetal ornaments in the Late Avar decorative art

Péter LANGó

Relations between the Carpathian Basin and South East Europe during the 10th century.

The evidence of the minor objects

Ciprián HoRvÁTH

The Cemeteries and Grave Finds of Györ and Moson Counties from the Time

of the Hungarian Conquest and the Early Árpádian Age

András Sófalvi

The border- and self-defence of Szeklers from the Medieval Age till the Age of Principality.

Castles and other defence objects in the settlement history of Udvarhelyszék 


\title{
Report on the participation of the Eötvös Loránd University at the Wielbark Archaeological Field School in Malbork-Wielbark, Poland
}

DÉNES Hullám

Déri Museum

Debrecen

hullamd@gmail.com
ZsófiA RÁcZ

Institute of Archaeological Sciences

Eötvös Loránd University

zsofia_racz@yahoo.de

\begin{abstract}
PhD, MA and BA students of the Institute of Archaeological Sciences (Eötvös Loránd University) took part in the Erasmus Archaeological Summer Field School in Malbork-Wielbark, Poland (Fig. 1) in $2012^{1}$ and 2013. ${ }^{2}$ The coordinator of the three years planned Erasmus intensive program is Dr. habil. Förg Kleemann (Humboldt-Universität zu Berlin) with the partnership of the universities of Poland (Uniwersytet Marie Curie-Skłodowskiej Lublin; Uniwersytet Szczeciński), Germany (Ruhr-Universität, Bochum), the Czech Republic (Univerzita Hradec Králové), Spain (Universidad Autónoma de Madrid) and Hungary (Eötvös Loránd University). News and results of the excavation are available at http://ipwafs.hu-berlin.de.
\end{abstract}

\section{History of the excavations at the Wielbark cemetery}

Malbork-Wielbark Site Nr. 1. is one of the most important cemeteries of the Wielbark-culture (named after this site), which dominated the Upper Vistula Region in the Late Iron and Imperial Ages. The territory of this archaeological culture is identified as the homeland of the Goths, Gepids and other Eastern Germanic tribes. ${ }^{3}$ The site is situated in a forest reservation in the bend of the Nogat River. A 1.5-2 m high sand layer covers the Late Iron Age Imperial Age cultural layer, which was moved here in the 13th century.

The cemetery is known from the 1870's due to some stray finds and a small excavation. ${ }^{4}$ The history of the archaeological field and its materials were connected very closely to military activities and political changes after World War I. The site was rediscovered when the army established a practicing ground in the forest. Excavations started with Kurt Voigtmann's leadership at the site called Willenberg Nr. 1. (so-called Heidnische Preussen). During the five years of the excavation seasons 1.5-2 hectares of Late Iron Age - Imperial Age biritual cemetery came to light, with the last grave number of 1733 in 1932. After some other small excavations in 1934 and 1936 nearly 140 new objects turned up. ${ }^{5}$ The results of the excavations have never been published. In 1945 the building of the city museum, where the finds

1 In the first season (08.07.2012 - 05.09.2012) Adrienn Blay, Bernadett Kovacsóczy, Anna Varga, Levente Samu, Zoltán Tóth and Dénes Hullám spent four weeks at the excavation with the leadership of Zsófia Rácz.

2 In the second season (07.07.2013 - 04.08.2013) Anna Koltai, Dóra Szabó, Júlia Trembeczki, Bence Gulyás, and Zalán András Szalai spent four weeks there with the leadership of Dénes Hullám.

3 Bierbrauer 1998, 407-418.

4 KLEEMANn 2010, 355.

5 KLEEMANN 2010, 356-357. 
and documentations were kept, have been destroyed. ${ }^{6}$ Researches only continued after a long break, when collaborators of the Malbork Castle Museum (Muzeum Zamkowe w Malborku) successfully identified the site with small trenches in the 1980s. ${ }^{7}$

In 2004 Jörg Kleemann found the copies of the Merienburg city museum's reports originating from between 1927 and 1931, in the library of the University of Fulda. ${ }^{8}$ Summarizing the history of the Wielbark find place, Kleemann determined: „Nunmehr bekommt der Mythos Wielbark stan. 1 „Heidnische Preussen” zumehmend ein reales Gesicht, das einerseits erschreckend ist in Hinsicht auf den fast vollständigen Verlust der archäologischen Funde sowie auch der Fotografen, Zeichnungen, Feldtagebücher und einer Kartothek mit zuletzt 762 Blättern über die wichtigsten Grabfunde umfassenden Dokumentation. Andererseits liegt nun für die großen Grabungen bis 1932 ein vollständiger Gräberfeldplan vor, der zusammen mit den mehr oder weniger ausführlichen Angaben der Jahresberichte den Ausgangspunkt für die Rekonstruktion des Gräberfeldes als archäologischer Quelle bildete." He digitalized the newly discovered maps and tried to interpret the documentations together with the reports. ${ }^{9}$

After this, new excavations started with the aim to localize former German excavation trenches and to find the borders of the cemetery. In 2008 and 2010 small field works were organised in the forest with the leadership of Jörg Kleemann, in a partnership with the University of Lublin. After the authentications the Erasmus-sponsored field school and planned excavations began in 2012 .

\section{The 2012 and 2013 excavation seasons}

In the beginning, the primary aspect of setting out trenches was to connect to former German excavations trenches (Fig. 2-3). In the first season more than 100, one year later further 100 new objects came to light from the 1st to 3rd centuries AD. New cremation graves occurred with 1-1.5 m diameter oval or circle-shaped pits with the remains of a pile (filled in with a great many of charcoal and some calcined bone fragments) or without this (light, sandy fill-in with less charcoal and calcined bone fragments). The graves or grave groups were usually marked with a whinstone. The burials were mainly dug into each other, sometimes pit complexes occurred (Fig. 4). Only a few urn graves were found in the new parts of the cemetery, in some cases with the remains of a pile (in strongly ashy pits) or just alone in the sand on a higher level (Fig. 5). Inhumations were also found in south-north oriented grave pits. In case it was possible to observe, skeletons were in a slightly contracted position. Inhumations were often disturbed by cremation burials, thus their pits with light filling slightly different from the subsoil were not always visible. Preservation conditions are very bad for bones in sandy subsoil, thus sometimes only small bone fragments or teeth marked the deceased (Fig. 6). In higher levels small circle-shaped, shallow pits were observed in superposition, with black, burned charcoal filling, but without any materials or human remains. The function of these pits are unknown, maybe they can be associated with rituals closing burials.

6 Selected materials from the cemetery were published in contemporary monographs: BoHNSACK 1938; SCHINDLER 1940.

7 KLEEMANN 2010, 357.

8 Subsisted Wielbark materials from former German excavations were published from various Polish museums in SEKUŁA 2006.

9 KLEEMANN 2010, 357-370. 
Typical archaeological materials from Wielbark-culture graves are most often elements of clothing or jewelleries: brooches (bronze or silver), bracelets (bronze or silver), beads, belt fittings and belt buckles.

The Achilles point of the Wielbark cemetery is the interpretation and chronological determination of the groups of cremations and inhumations. It can be presumed that superpositions are not occasional, but conscious ground using is possible. Small social or family groups received certain places where they buried for a long period of time.

The site of Wielbark has a significant importance in the region's history in the Late Iron and Imperial periods. Although only sporadically, some elements of this cultural circle arrived to the Carpathian Basin as well. The work carried out within the archaeological field school and in corporation with various universities has given new experiences to the participants. In the next season, in 2014 the international field school will continue with the goal of locating the western and northern borders of the cemetery.

\section{Bibliography}

Bierbrauer, V. 1998: s.v. Goten. II. Archäologisches. In: Reallexikon der Germanischen Altertumskunde 12. Berlin - New York, 407-426.

Bohnsack, D. 1938: Die Burgunden in Ostdeutschland und Polen während des letzten fahrhunderts v. Chr. Lepzig.

KleEmann, J. 2010: Mehr als ein Mythos - Bemerkungen zum Gräberfeld von Malbork-Wielbark. In: Theune, C. - Biermann, F. - Struwe, R. - H. Jeute, G. (Hrsg.), Zwischen Fjorden und Steppe. Festschrift für fohan Callmer zum 65. Geburtstag. Internationale Archäologie, Studia honoraria Bd. 31. Rahden/Westf., 355-374.

SCHINDLER, R. 1940: Die Besiedlungsgeschichte der Goten und Gepiden im unteren Weichselraum auf Grund der Tongefäße. Leipzig.

Seku£A, M. 2006: Ocalałe zabytki pochodzące z badań niemeckich na cmentarzysku w MalborkuWielbarku w zbiorach muzeów polskich. In: Nowakowski, W. - Szela, A. (eds.), Pogranicze trzech światów. Kontakty kultur przeworskiej, wielbarskiej i bogaczewskiej w świetle materiałów $z$ badań i poszukiwań archeologicznych. Warszawa, 175-223. 


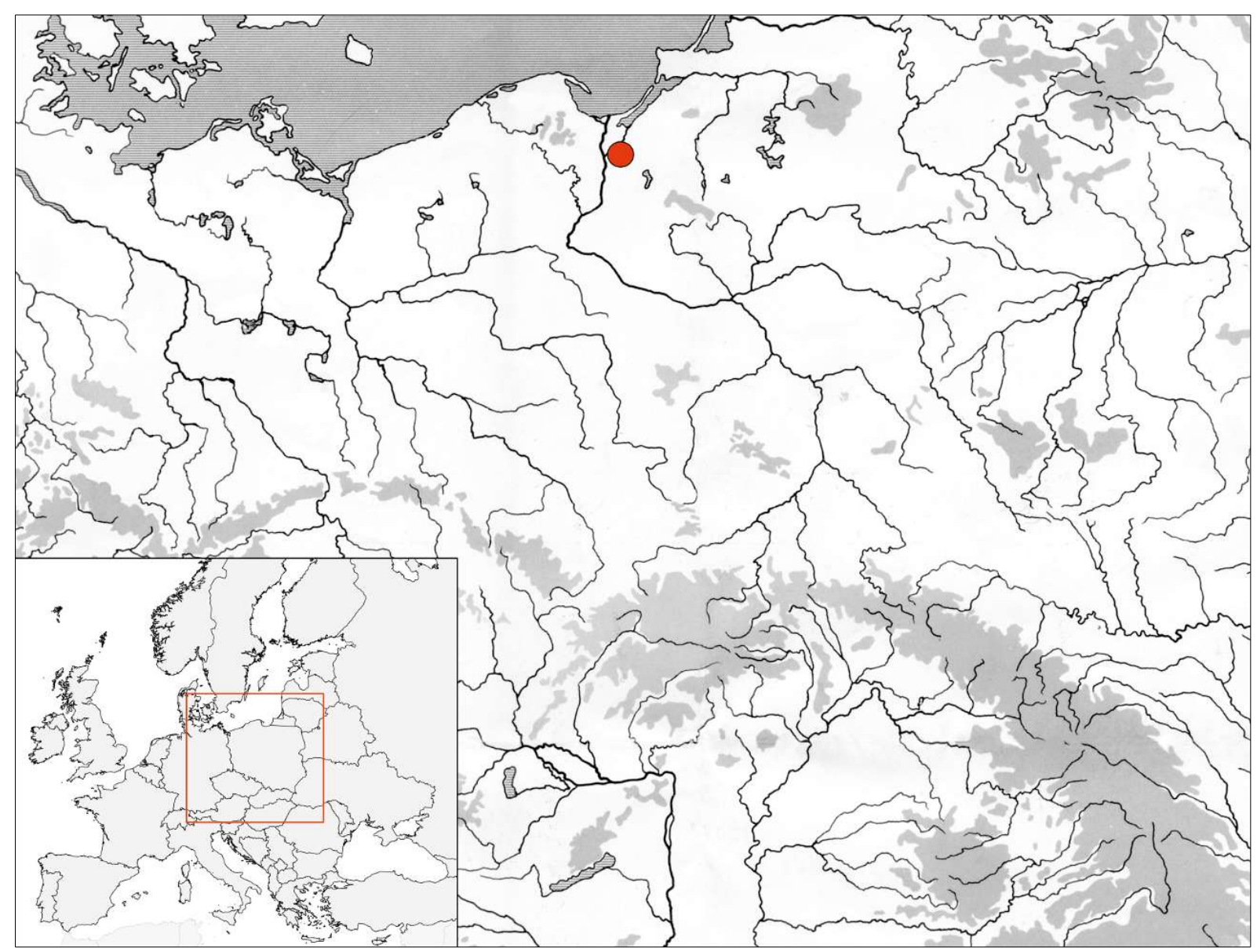

Fig. 1. The distribution area of the Wielbark culture and Malbork-Wielbark Site Nr. 1.

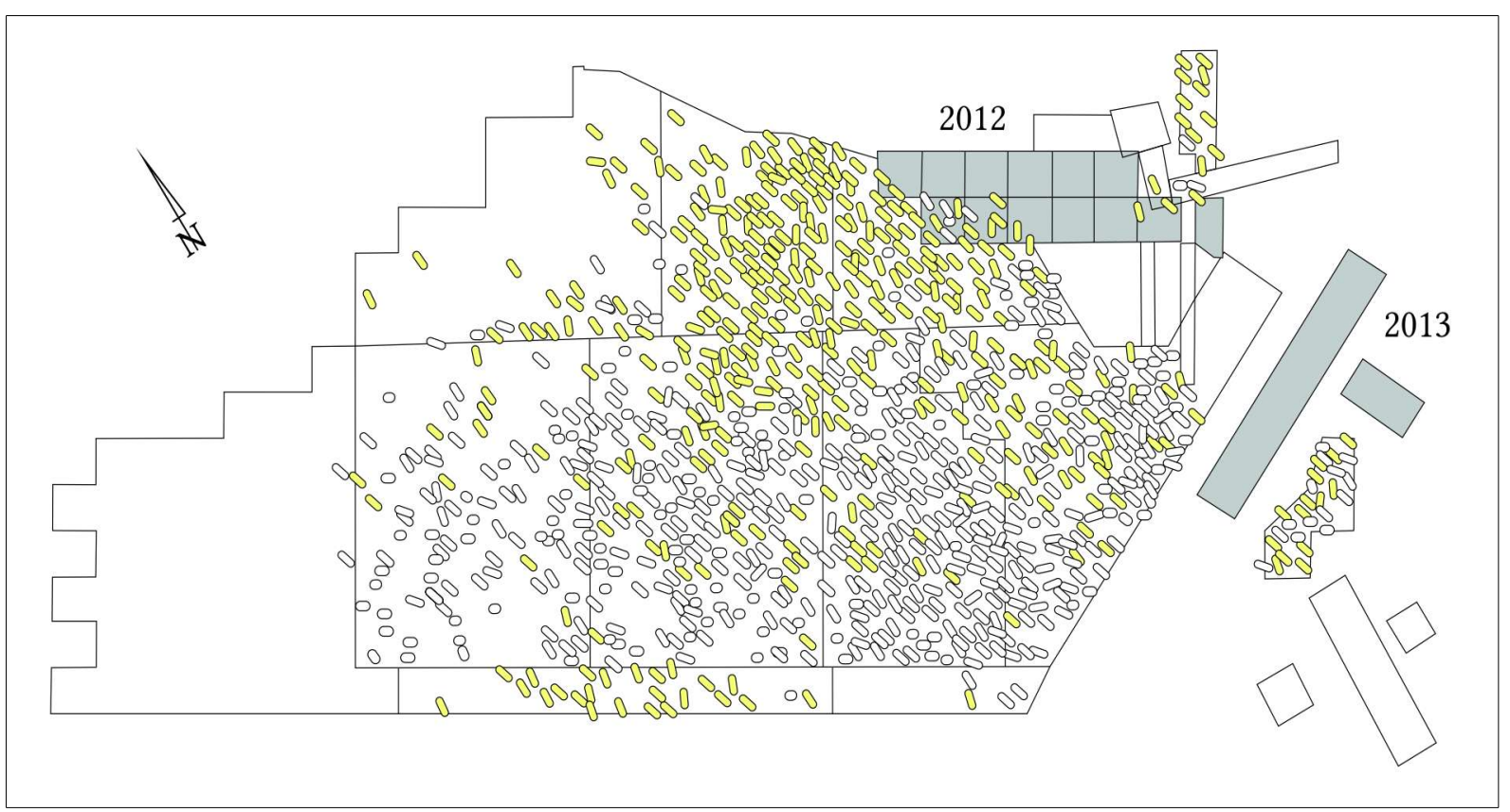

Fig. 2. Malbork-Wielbark Nr. 1: Trenches of former German excavations (1927-32) and the new research. 


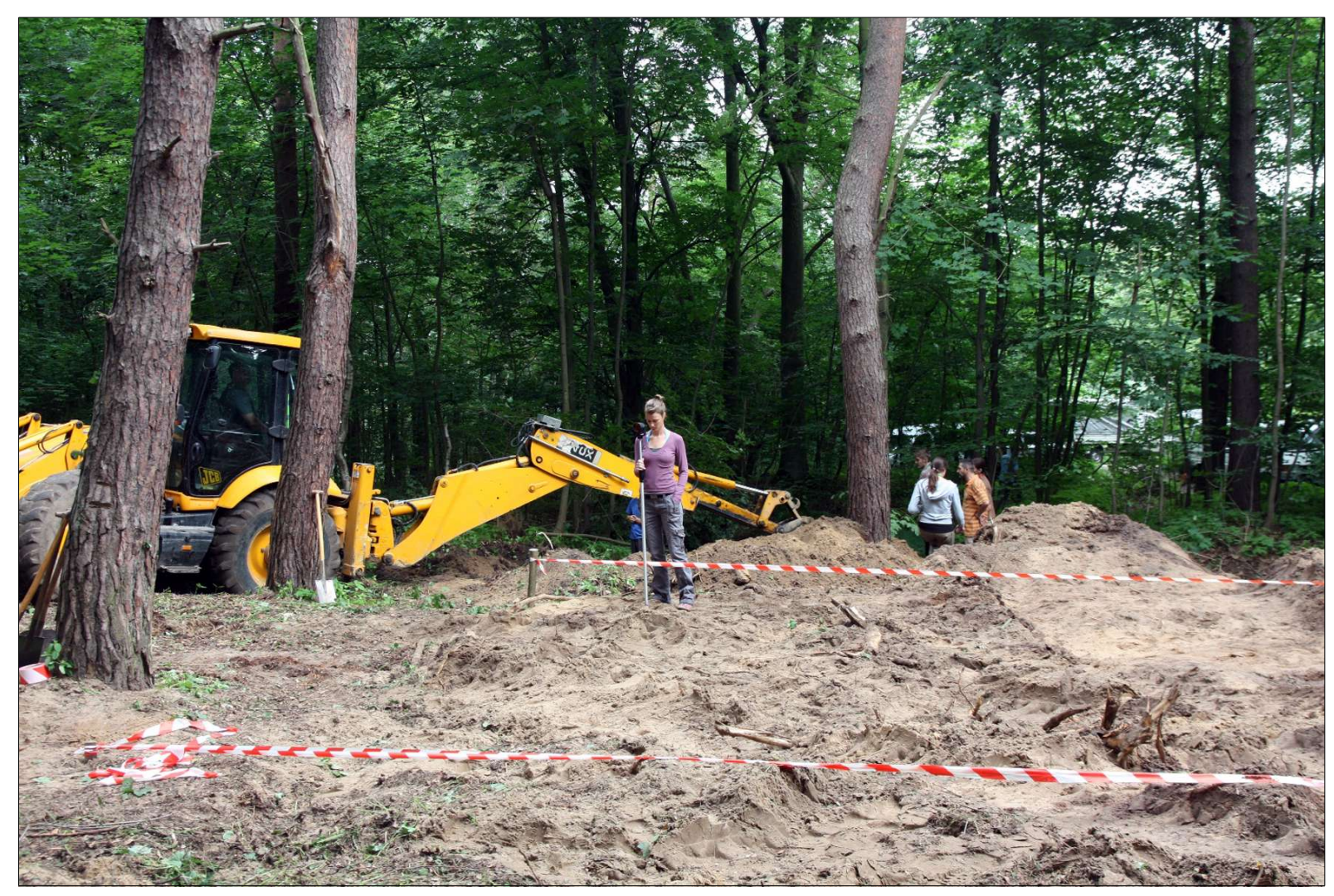

Fig. 3. Malbork-Wielbark Nr. 1: After deforestation and before topsoil stripping in 2012.
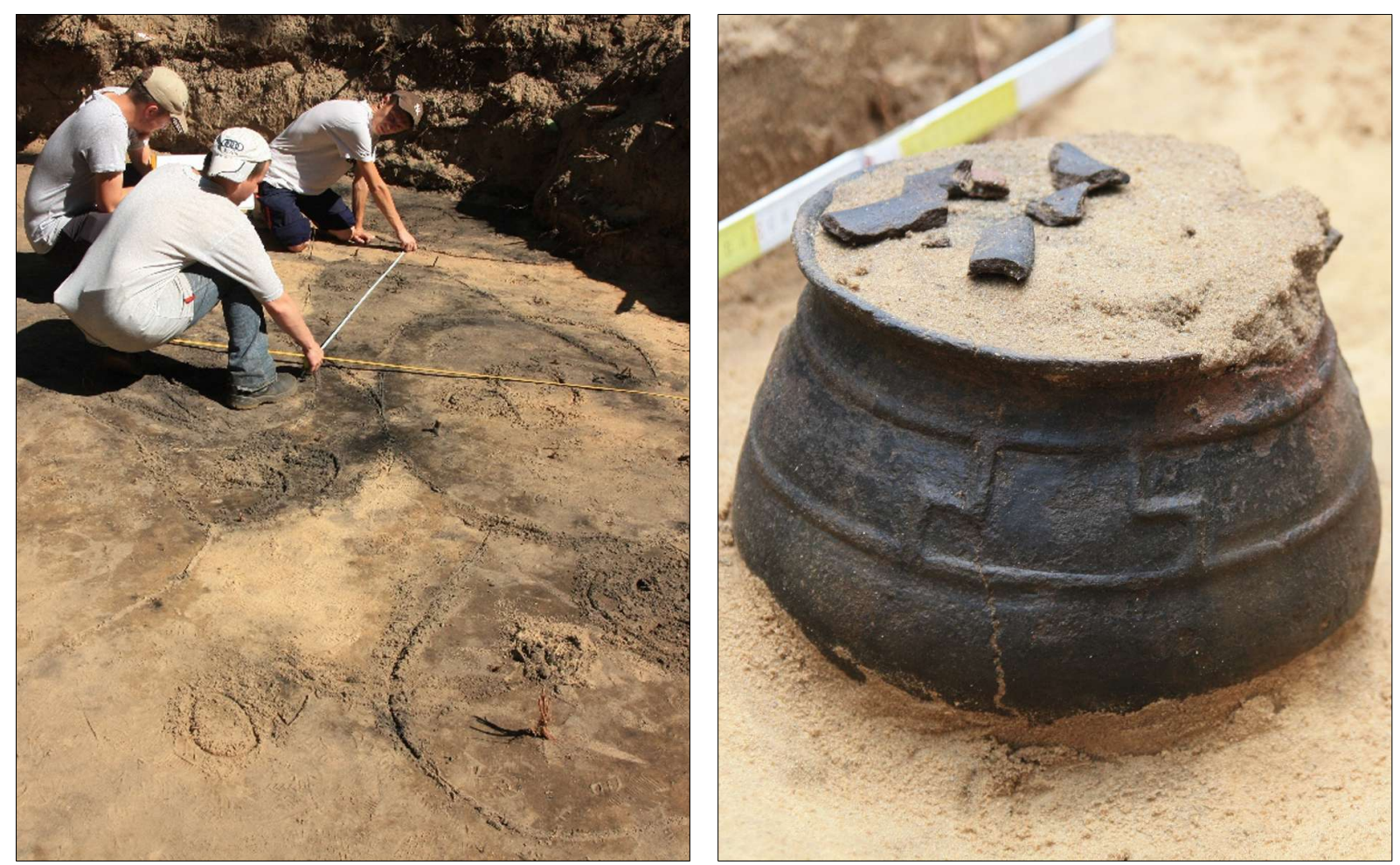

Fig. 4-5. Malbork-Wielbark Nr. 1: Spots of cremation graves in trench No. 1. (left) and urn grave (right) in 2012. 


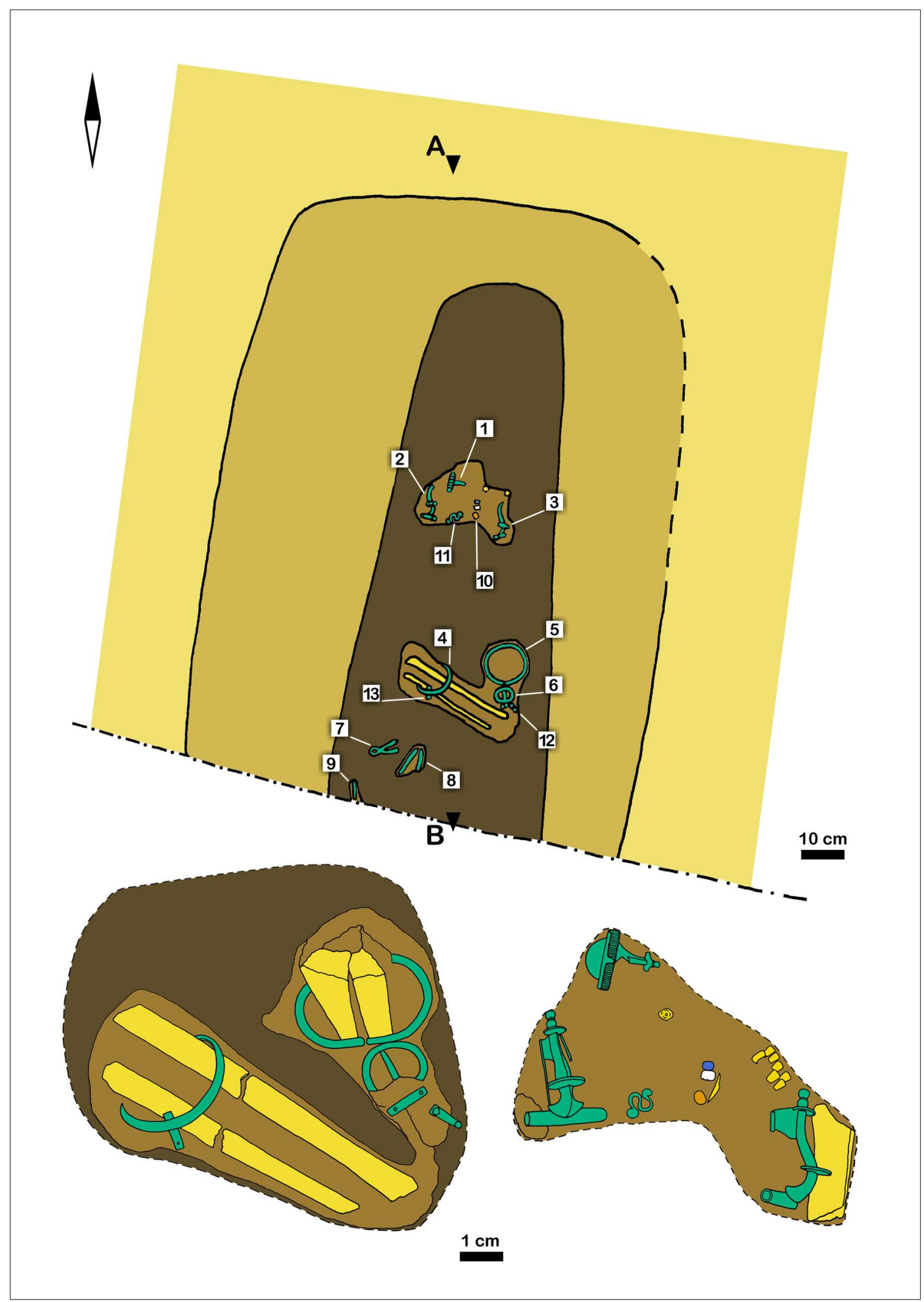

Fig. 6. Malbork-Wielbark Nr. 1: Inhumation grave in 2012 (Drawing: L. Samu - A. A. Király). 